\title{
Antibacterial, cytotoxicity and metabolite profiling of crude methanolic extract from andaliman (Zanthoxylum acanthopodium) fruit
}

\author{
MADA TRIANDALA SIBERO ${ }^{1,2, \boldsymbol{v}}$, ANGGUN PUSPITARINI SISWANTO ${ }^{3}$, RETNO MURWANI ${ }^{2,4}$, \\ EVAN HANSEL FREDERICK ${ }^{1,2}$, ALDI PRATAMA WIJAYA ${ }^{1,2}$, EMMY SYAFITRI ${ }^{5}$, KINDI FARABI ${ }^{6}$, \\ SHUN SAITO $^{7}$, YASUHIRO IGARASHI
}

${ }^{1}$ Department of Marine Science, Faculty of Fisheries and Marine Science, Universitas Diponegoro. Jl. Prof. Soedarto S.H., Tembalang, Semarang 50275, Central Java, Indonesia. Tel.: +62-24-7474698, Fax.: +62-24-7474698, `email: madatriandalasibero@lecturer.undip.ac.id

${ }^{2}$ Natural Product Laboratory, Integrated Laboratory for Research and Services, Universitas Diponegoro. Jl. Prof. Soedarto S.H., Tembalang, Semarang 50275, Central Java, Indonesia

${ }^{3}$ Chemical Engineering, Vocational School, Universitas Diponegoro. J1. Prof. Soedarto S.H., Tembalang, Semarang 50275, Central Java, Indonesia

${ }^{4}$ Department of Animal Science, Faculty of Animal Science and Agriculture, Universitas Diponegoro. Jl. Prof. Soedarto S.H., Tembalang, Semarang 50275, Central Java, Indonesia

${ }^{5}$ Faculty of Fisheries, Universitas Dharmawangsa. J1. KL Yos Sudarso No. 224, Glugur Kota, Medan 20115, North Sumatra, Indonesia

${ }^{6}$ Department of Chemistry, Graduate School of Science, Osaka University. 1-1 Machikaneyama-cho, Toyonakam Osaka 560-0043, Japan ${ }^{7}$ Biotechnology Research Center, Toyama Prefectural University. 5180 Kurokawa, Imizu, Toyama 939-0398, Japan

Manuscript received: 21 July 2020. Revision accepted: 15 August 2020.

\begin{abstract}
Sibero MT, Siswanto AP, Frederick EH, Wijaya AP, Syafitri E, Farabi K, Murwani R, Saito S, Igaras Y. 2020. Antibacterial, cytotoxicity and metabolite profiling of crude methanolic extract from andaliman (Zanthoxylum acanthopodium) fruit. Biodiversitas 21: 4147-4154. The local community in North Sumatra has utilized andaliman fruit (Zanthoxylum acanthopodium) as spices for traditional cuisines because it has a unique flavor. Information on the antimicrobial activity of $Z$. acanthopodium fruit against aquaculture pathogens and its bioactivity against leukemia cell lines are limited. The purposes of this study were to evaluate the antimicrobial activity of Z. acanthopodium fruit against Tenacibaculum maritimum, Vibrio alginolyticus, $V$. anguillarum, $V$. harveyi that are known as pathogens in aquaculture; to determine cytotoxic property against murine P388 leukemia cells; and to characterize its metabolites profile. The sample was extracted using methanol by the maceration method. Antibacterial assay was conducted by Kirby-Bauer disc diffusion method; while cytotoxicity assay using the XTT method. Proximate analysis showed that Z. acanthopodium fruit contained $63.41 \%$ of moisture, $24.73 \%$ of crude fiber, $9.81 \%$ of crude protein, $6.90 \%$ of ash, and $2.55 \%$ of crude fat. Several phytochemical components were detected, such as alkaloid, flavonoid, tannin, triterpenoid, and steroid. The GC/MS analysis indicated the presence of various compounds from terpenoid and terpenes derivatives. This study indicated that $Z$. acanthopodium fruit was not potential as antibacterial agents against the aquaculture pathogens; however, the methanol extract showed cytotoxic potential with $\mathrm{IC}_{50} 19.14 \mu \mathrm{g} / \mathrm{mL}$ against murine P388 leukemia cells.
\end{abstract}

Keywords: Andaliman, cytotoxicity, leukemia, terpenes, Zanthoxylum

\section{INTRODUCTION}

The genus Zanthoxylum is a member of the Rutaceae family, with 225 species found in pantropic countries (Appelhans et al. 2018). In Indonesia, Zanthoxylum acanthopodium, known as andaliman or tuba (in Karonese language), is a species that grows in North Sumatra, Indonesia. This plant was reported to grow in Dairi, North Tapanuli, Sidikalang, Simalungun, Sumbul, and several districts around Lake Toba (Siregar 2003; Sinaga et al. 2015; Asbur and Khairunnisyah 2018; Junaedi and Nurlaeni 2019; Saragih and Arsita 2019). Z acanthopodium fruit is commonly used in traditional cuisine because it gives a unique flavor and taste (Wijayaet al. 2002; Purba et al. 2018; Wijaya et al. 2019). There is still limited information on the use of $Z$. acanthopodium as a traditional medicine in the community in North Sumatra (Kristanty and Suriawati 2015; Saragih and Arsita 2019).

This plant is well known as a potential producer of essential oils (Wijaya et al. 2002; Asbur and Khairunnisyah 2018; Wijaya et al. 2019). The unique flavor of Z. acanthopodium essential oils due to volatile compounds such as $\beta$-myrcene, limonene, and citronellal (Wijaya et al. 2019). Previous studies showed the potency of $Z$. acanthopodium as an antioxidant, antibacterial against human pathogens, anti-inflammatory, and antiacne (Julistiono et al. 2018; Wijaya et al. 2019). The potency of Z. acanthopodium against breast (T47D and 4T1), and cervical cancer cell (HeLa) lines were reported previously (Rosidah et al. 2019; Satria et al. 2019; Syari et al. 2019). However, its potency against leukemia cancer cells has not been determined yet. Leukemia is one of the five types of cancer that causes the highest mortality in Indonesia (WHO 2019). Due to this condition, Z. acanthopodium is expected to have cytotoxic activity against leukemia cancer cells.

Besides its therapeutic benefits, $Z$. acanthopodium is expected to be used in more widely application such as in the aquaculture industry. One of the common problems in aquaculture is a pathogenic infection caused by Tenacibaculum maritimum, Vibrio alginolyticus, $V$. anguillarum, V. harveyi (Li et al. 2018; Liu et al. 2016; 
Småge et al. 2016). The administration of antibiotics in aquaculture to cure or prevent infection has become a serious problem since it leads to antimicrobial resistance in pathogens (Mo et al. 2015; Santos and Ramos 2018). Moreover, the residue of antibiotic in aquaculture practices also threaten consumer's health and cause a microbial disturbance in the aquatic environment (Hedberg et al. 2018; Liu et al. 2017). Since Z. acanthopodium has been reported as a potential antimicrobial against human pathogens, this plant is also expected to exhibit the same activity against aquaculture pathogens. Hence, the purposes of this study were to evaluate the antibacterial activity against aquaculture pathogens, evaluate cytotoxic activity against P388 leukemia cancer cells, as well as to characterize metabolites using proximate analysis, phytochemical and chromatography approach.

\section{MATERIALS AND METHODS}

\section{Sample preparation}

One $\mathrm{kg}$ of $Z$. acanthopodium fruit was purchased from a local farmer in Parsoburan Village, Toba Samosir District, North Sumatra, Indonesia in September 2018. Identification was carried out at the Dharmawangsa University, Medan, Indonesia. The sample was packed in a Styrofoam box to maintain the quality during the shipping process to the Laboratory of Natural Products, Diponegoro University, Semarang, Indonesia. Z. acanthopodium was air-dried under sunshine. Furthermore, the sample was ground using a blender.

\section{Proximate analysis}

A total of $200 \mathrm{~g}$ of fresh $Z$. acanthopodium was used for proximate analysis, (moisture, ash, crude fiber, crude protein, and crude lipid) according to the AOAC method (AOAC 2019).

\section{Metabolite extraction}

A total of $240 \mathrm{~g}$ of the powdered $Z$. acanthopodium fruit was extracted with methanol with agitation (120 r.p.m., $27^{\circ} \mathrm{C}$ ) for $24 \mathrm{~h}$. The filtrate was concentrated using a rotary evaporator at $30-35{ }^{\circ} \mathrm{C}$, and the concentrated extract was partitioned with ethyl acetate using a separating funnel. Ethyl acetate extract was concentrated with a rotary evaporator.

\section{Phytochemical analysis}

Phytochemical analysis was done to determine the phytochemical compounds of $Z$. acanthopodium. Qualitative detection of phytochemical compounds was carried out as follow:

\section{Alkaloid}

Five grams of $Z$. acanthopodium fruit powder was immersed in $15 \mathrm{~mL}$ of $2 \mathrm{~N}$ sulfuric acid for 15 minutes and then filtered using filter paper. The filtrate was divided into three and put into three test tubes. Each test tube contained $5 \mathrm{~mL}$ of extract. Dragendorff, Mayer, and Wagner reagents were added to the test tube, then the precipitation on the bottom of the test tube was observed. The presence of alkaloids was indicated by the presence of orange to reddish precipitation when added with Dragendorff, white to yellowish precipitation when added with Mayer and brown precipitation when added with Wagner (Harborne 1973; Bhandary et al. 2012).

\section{Flavonoid}

The detection of flavonoids was done using the Shinoda method as follows: two grams of $Z$. acanthopodium fruit powder was extracted with $10 \mathrm{~mL}$ of ethanol $96 \%$ without evaporation. A test tube containing $5 \mathrm{ml}$ ethanol extract was added with $0.1 \mathrm{mg}$ of Magnesium powder and $1 \mathrm{~mL}$ of amyl alcohol, then shaken. Then, $4 \mathrm{~mL}$ of ethanol was added to the wall of the test tube carefully. The formation of yellow/orange to reddish color in the amyl alcohol layer indicated the presence of flavonoids (Bhandary et al. 2012; María et al. 2018).

\section{Saponin}

One gram for $Z$. acanthopodium fruit powder was added with $7 \mathrm{~mL}$ of water in a test tube and then heated to boiling. Shake test tube vigorously until the foam layer was formed then left for $30 \mathrm{~min}$. The stability of the foam layer was tested by the addition of 1 drop of $2 \mathrm{~N} \mathrm{HCl}$. A stable foam after the stability test indicated the presence of saponin (Bhandary et al. 2012; María et al. 2018).

\section{Tannin}

Ferric chloride test was carried out to detect the presence of tannin in the $Z$. acanthopodium water extract. Two drops of $1 \% \mathrm{FeCl} 3$ were added into $2 \mathrm{~mL}$ of $Z$. acanthopodium water extract. A presence of greenish to the black color indicated the presence of tannin (María et al. 2018; Pringgenies et al. 2018).

\section{Steroid/triterpenoid}

The Liebermann-Burchard test detected steroid/ triterpenoid. Three $\mathrm{mL}$ of methanol extract was mixed with several drops of acetic anhydride, then heated using a water bath and cooled down. Several drops of concentrated $\mathrm{H}_{2} \mathrm{SO}_{4}$ were added gently through the side of the test tube. The formation of green color in the upper layer and deep red color in the lower layer indicated the presence of steroid/terpenoid (Bhandary et al. 2012; Seow et al. 2013).

\section{Quinone}

Borntraeger reaction was performed to detect the presence of free quinones in the $Z$. acanthopodium methanol extract. Two $\mathrm{mL}$ of methanol extract was transferred into the test tube, then $1 \mathrm{~mL}$ of $2 \mathrm{~N} \mathrm{NaOH}$ was added. The formation of pink to red/violet color indicated the presence of quinone (Khlif et al. 2015; María et al. 2018).

\section{GC/MS analysis}

GC/MS analysis was performed using Shimadzu GCMS-QP2010 SE and Rtx-5MS column package $(0.25$ $\mathrm{mm} \times 30 \mathrm{~m}, 0.25 \mu \mathrm{m}$ ). One $\mu \mathrm{L}$ sample (concentration 1 $\mathrm{mg} / \mathrm{mL}$ ) was injected in split mode at a temperature of 300 
${ }^{\circ} \mathrm{C}$. The carrier gas was Helium $(\mathrm{He})$ with a flow of 0.74 $\mathrm{mL} / \mathrm{min}$ and linear velocity at $31.8 \mathrm{~cm} / \mathrm{sec}$. The chemical content of $Z$. acanthopodium fruit was identified by comparing the result with the database in the laboratory computer.

\section{Bioassay \\ Antibacterial assay}

Zanthoxylum acanthopodium extract was tested against aquaculture pathogens (Tenacibaculum maritimum, Vibrio alginolyticus, $V$. anguillarum, $V$. harveyi). The aquaculture pathogens were revived from the frozen stock culture and cultured on marine agar (MA, Difco), then incubated for 48 $\mathrm{h}$ at $37^{\circ} \mathrm{C}$. All pathogens were sub-cultured on agar for 24 $\mathrm{h}$ before being used for antibacterial test using the modified Kirby-Bauer disc diffusion method (Sibero et al. 2019.) The extract was diluted in DMSO to a concentration of 2 $\mathrm{mg} / \mathrm{mL}$. In addition, DMSO was used as negative control while Chloramphenicol $30 \mu \mathrm{g} / \mathrm{mL}$ was used as a positive control. The presence of clear zone indicates growth inhibition of aquaculture pathogens

\section{Cytotoxicity assay}

The cytotoxic assay was performed against P388 murine leukemia cells in 96-well plates. The XTT cytotoxicity method was carried out. Extract was diluted into 5 concentrations $(0.0025 ; 0.025 ; 0.25 ; 2.5$ and 25 $\mu \mathrm{g} / \mathrm{mL})$. DMSO was set up as negative control and doxorubicin as a positive control. Cell preparation and cytotoxic assay were performed, according to Sharma et al. (2019). Cells treated with extract and controls were incubated for $72 \mathrm{~h}$ at $37^{\circ} \mathrm{C}$, an atmosphere of $5 \% \mathrm{CO}_{2}$ in the air with $100 \%$ humidity. Then the $50 \mu \mathrm{L}$ of XTT was added into each well then re-incubated for four $h$ in the same condition. The absorbance was read using a microplate reader at $450 \mathrm{~nm}$. The data were plotted on the logarithmic chart to calculate the $\mathrm{IC}_{50}$ of the crude extract and doxorubicin.

\section{RESULTS AND DISCUSSION}

Proximate analysis was performed to determine primary metabolites of $Z$. acanthopodium fruit. The result of this analysis is presented in Table 1 . The result of proximate analysis (Table 1) showed moisture content of fresh $Z$. acanthopodium fruit was $61.71 \%$. Z . acanthopodium fruit contained $24.73 \%$ of crude fiber, $9.81 \%$ of crude protein, $6.90 \%$ of ash, $2.55 \%$ of crude fat based on a dry weight basis. This result was similar to a previous report by Asbur and Khairunnisyah (2018). Their study stated that the dried Z. acanthopodium fruit content $25.98 \%$ of carbohydrate and $8.01 \%$ of essential oil. Carbohydrates content in this study was not determined. There is a significant difference between the results of this study with the results of the previous analysis by Asbur and Khairunnisyah (2018) on ash and protein contents was noted between our result and the previous study. Plant maturity, environmental stress and disturbance, fertilizer, geographical distribution and drying method affect an important influence to the proximate content in the plant (Khattak and Rahman 2015; Kovach et al. 1992; Mbah et al. 2012; Oduntan and Olaleye 2012; Vihotogbe et al. 2013) which were not evaluated in this current study. Therefore, the difference of ash and protein contents in our study to the reference was also suggested as the result of those unevaluated variables.

In this study, phytochemical screening was carried out to determine secondary metabolites of $Z$. acanthopodium fruit. The result was presented in Table 2 . The phytochemical analysis showed $Z$. acanthopodium fruit contained alkaloid, flavonoid, saponin, steroid, triterpenoid, and tannin. A review by Singh and Singh (2011) showed that Zanthoxylum extract contained various derivatives compounds from alkaloids, amides, coumarins, flavonoids, lignin, terpenoids, sterols, and steroid. Further analysis using GC/MS showed 20 identified compounds (Figure 1 and Table 3).

The result of the GC/MS analysis successfully identified 20 chemical compounds in the methanol extract of $Z$. acanthopodium fruit. Sixteen chemical compounds are terpenes and terpenoids derivatives. The other four chemical compounds were structurally identified as aliphatic derived compounds (neoherculin; ethyl linoleate; ethanol, 2-(3,3-dimethylcyclohexylidene)-; and 9,12Octadecadienoyl chloride). All of these compounds have been reported in previous studies as secondary metabolites of Zanthoxylum species (Kumar et al. 2016; da Silva et al. 2017; Singh and Singh 2011; Wijaya et al. 2002, 2019) as the component of essential oils from $Z$. acanthopodium. The results showed that the main compounds of $Z$. acanthopodium fruit from Parsoburan village, Toba Samosir, North Sumatra were geranyl acetate (26.72\%) and neoherculin $(20.99 \%)$

Table 1. Proximate composition of Zanthoxylum acanthopodium fruit

\begin{tabular}{lll}
\hline \multirow{2}{*}{ Proximate content } & \multicolumn{2}{c}{ Composition } \\
\cline { 2 - 3 } & $\begin{array}{l}\text { Current } \\
\text { study }\end{array}$ & Reference* \\
\hline Wet weight & $150 \mathrm{~g}$ \\
Moisture & $63.41 \%$ & $61.71 \%$ \\
Dry weight & $54.89 \mathrm{~g}$ & \\
Ash & $6.90 \%$ & $1.80 \%$ \\
Crude fat & $2.55 \%$ & $2.58 \%$ \\
Crude protein & $9.81 \%$ & $1.93 \%$ \\
Crude fiber & $24.73 \%$ & $\mathrm{NR}$ \\
Miscellaneous (carbohydrate, oil, etc.) & $56.01 \%$ & $\mathrm{NR}$ \\
Carbohydrate & NT & $25.98 \%$ \\
Atsiri oil & $\mathrm{NT}$ & $8.01 \%$ \\
\hline Note: “*” referred to Asbur and Khairunnisyah (2018); NT: not \\
tested; NR: not reported & \multicolumn{2}{l}{} \\
\end{tabular}

Table 2. Phytochemical compounds of Zanthoxylum acanthopodium fruit

\begin{tabular}{|c|c|c|c|}
\hline $\begin{array}{l}\text { Bioactive } \\
\text { content }\end{array}$ & Result & $\begin{array}{l}\text { Bioactive } \\
\text { content }\end{array}$ & Result \\
\hline Alkaloid & Positive & Saponin & Positive \\
\hline Flavonoid & Positive & Steroid/triterpenoid & Positive \\
\hline Quinone & Negative & Tannin & Positive \\
\hline
\end{tabular}




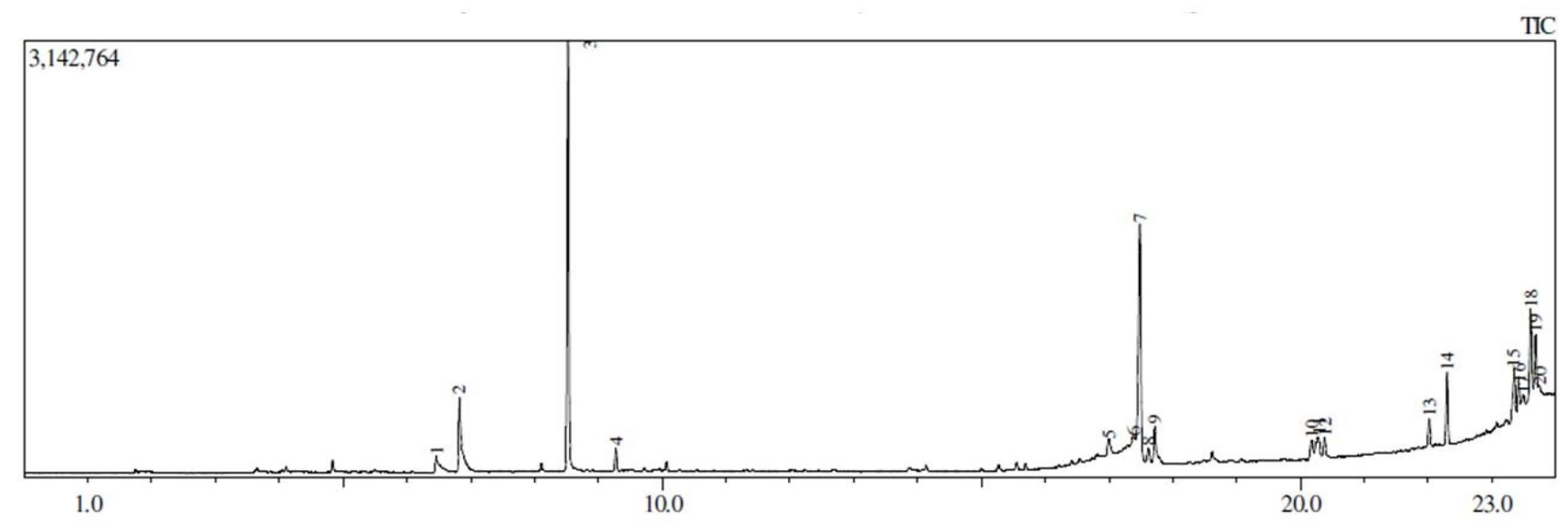

Figure 1. Gas chromatogram of Zanthoxylum acanthopodium fruit extract

Table 3. Identified chemical content of Zanthoxylum acanthopodium fruit

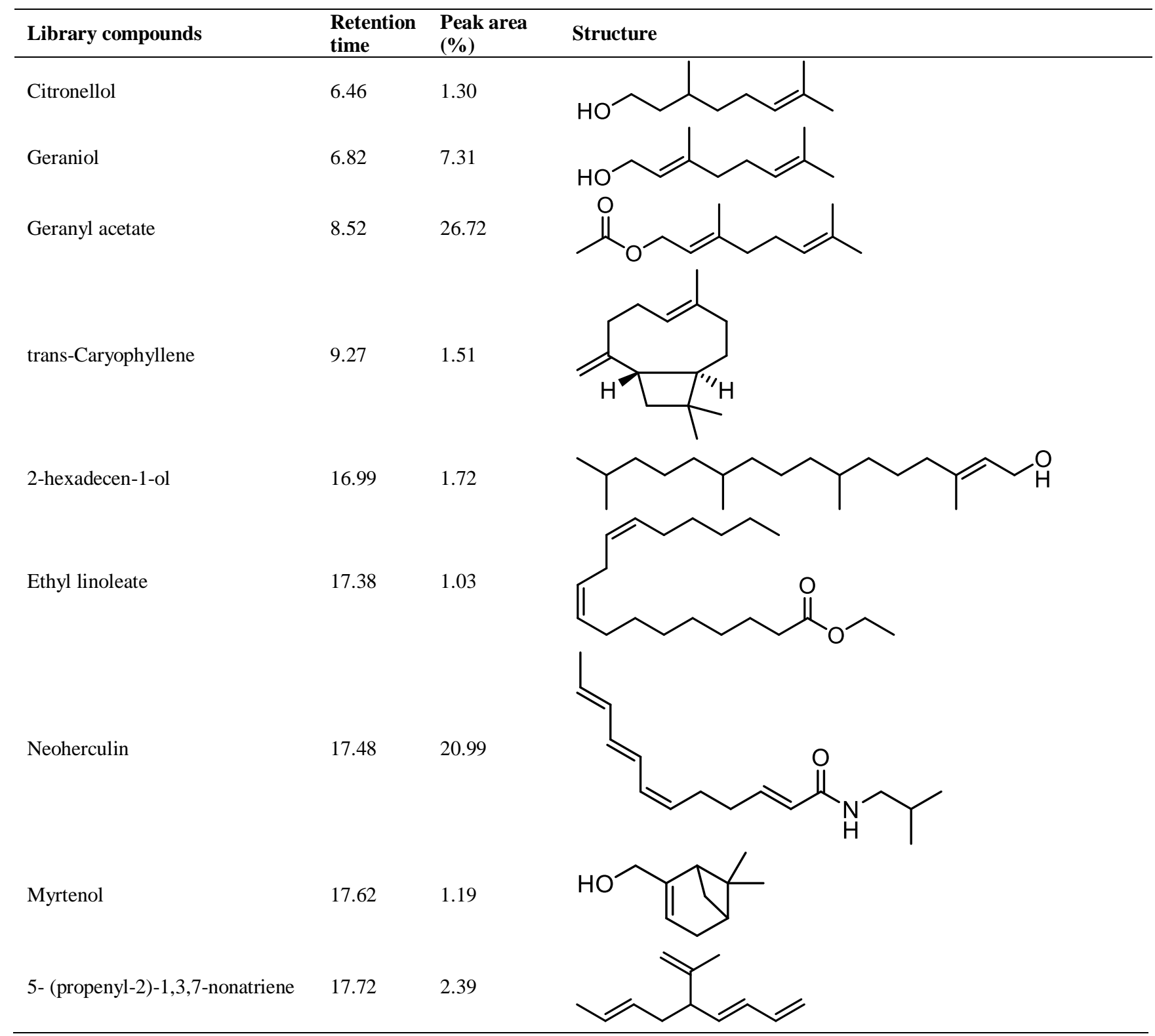


9,12-Octadecadienoyl chloride

$(E, E)$-farnesylacetone

Farnesol

Citronellyl propionate

Geranyl hexanoate

Citronellyl acetate

1,5,9-decatriene, $2,3,5,8-$ tetramethyl

trans-Geraniol

Ethanol, 2- (3,3-

dimethylcyclohexylidene)-

Myrtenyl acetate

Neryl butanoate

23.75<smiles>CCCCCC=CCC=CCCCCCCCC(=O)Cl</smiles><smiles>CC(=O)C1C/C=C(\C)C2C/C=C(\C)C(CC=C(C)C)/C(=C\CO)CC/C=C(/CC/C=C(/C)C1CC=O)C2</smiles><smiles>CCC(=O)OCCC(C)CCC=C(C)C</smiles><smiles>CCCCCC(=O)OC/C=C(\C)CCC=C(C)C</smiles><smiles>CC(=O)OCCC(C)CCC=C(C)C</smiles><smiles>C=CC(C)CC=C(C)CC(C)C(=C)C</smiles><smiles>CC(C)=CCC/C(C)=C/CO</smiles><smiles>CC1(C)CCC/C(=C\CO)C1</smiles><smiles>CC1(C)C2CCC(CCC(=O)O)C1C2</smiles><smiles>CCCC(=O)OC/C=C(/C)CCC=C(C)C</smiles>

The result of the antibacterial activity of $Z$. acanthopodium fruit against aquaculture pathogens is presented in Table 4.

Table 4. Antibacterial activity of Zanthoxylum acanthopodium fruit

\begin{tabular}{lc}
\hline Aquaculture pathogens & Antibacterial activity \\
\hline Tenacibaculum maritimum & NA \\
Vibrio alginoliticus & NA \\
Vibrio anguillarum & NA \\
Vibrio harveyi & NA \\
\hline
\end{tabular}

Note: NA: not active. Antibacterial assay was done using a concentration of $2 \mathrm{mg} / \mathrm{mL}$
Several previous studies showed that $Z$. acanthopodium has antibacterial activity against some of the human pathogens bacteria. Julistiono et al. (2018) reported that the hexane extract of $Z$. acanthopodium fruit showed antibacterial activities against Mycobacterium smegmatis. A study by Muzafri et al. (2018) showed that the methanol extract had better antibacterial activity than water and hexane extracts against E. coli, Salmonella typhimurium, and $S$. aureus. However, the results of this study showed that the methanol extract of $Z$. acanthopodium fruit did not exhibit any antibacterial activity against aquaculture pathogens ( $T$. maritimum, Vibrio alginoliticus, $V$. anguillarum, $V$. harveyi). The absence of antibacterial 
property in this study may be due to several factors such as unsuitable organic solvents to extract antibacterial compounds and the inability of the metabolites to inhibit the pathogens (Bacon et al. 2017). Zanthoxylum species are widely reported to have antimicrobial properties (Julistiono et al. 2018; Muzafri et al. 2018), unfortunately, only a few works determine the lead compounds. Tantapakul et al. (2012) successfully isolated 10 compounds from $Z$. rhetsa, however only one compound, dihydro chelerythrine, performed moderate antibacterial activity against $S$. aureus and E. coli. There has been no report on the lead compounds of $Z$. acanthopodium fruit, which have antibacterial property.

In this study, the cytotoxic activity of $Z$. acanthopodium against murine P388 leukemia cells was carried out. The result is presented in Figure 2 and Figure 3.

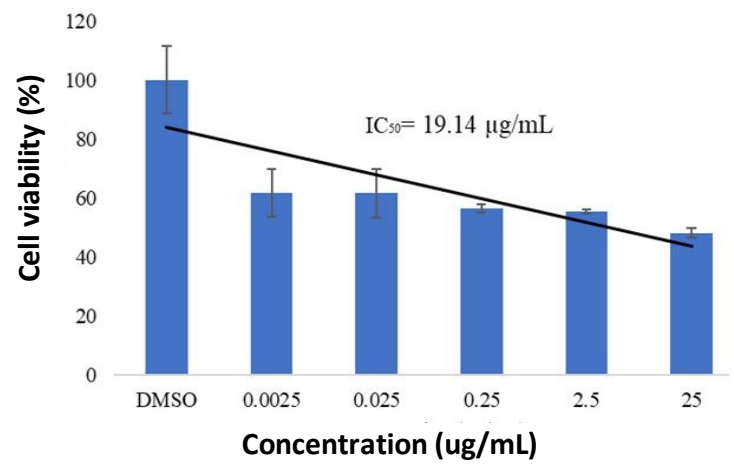

A

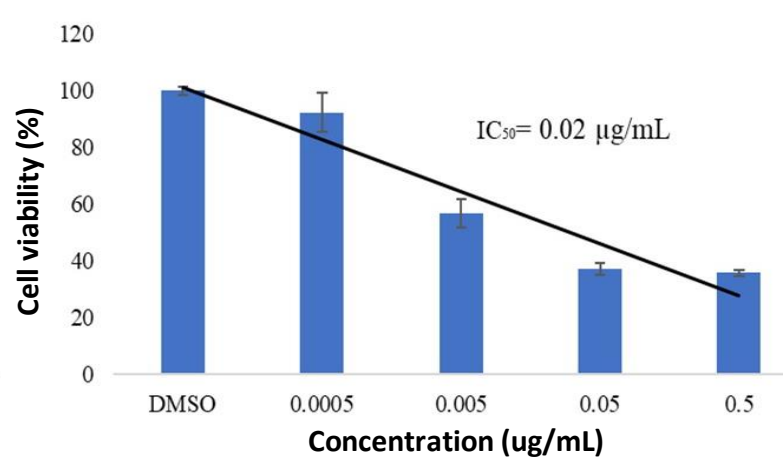

B

Figure 2. Percentage of viable murine P388 leukemia cells treated with Zanthoxylum acanthopodium fruit extract (A) and doxorubicin (B)

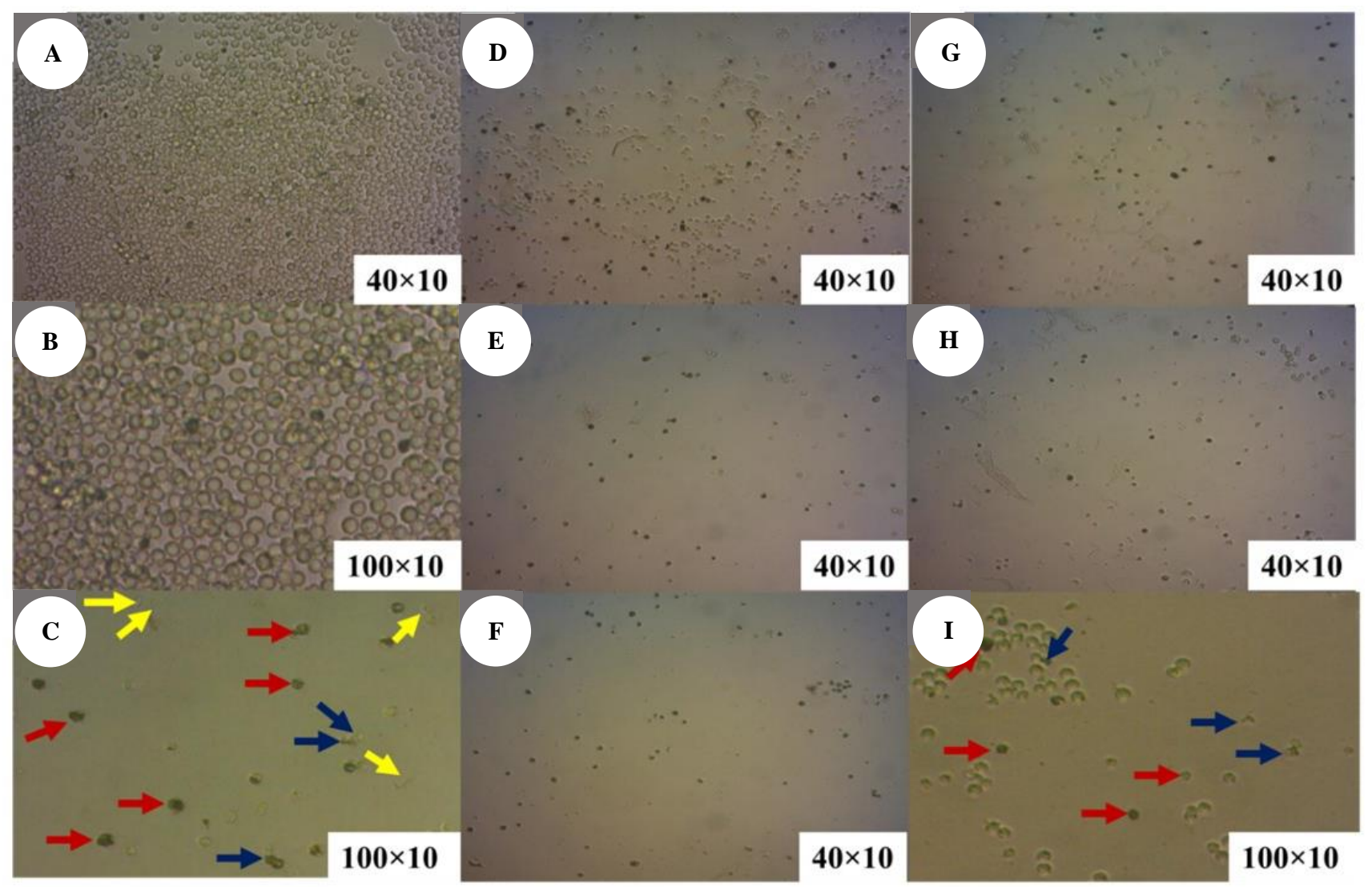

Figure 3. Morphological changes of murine P388 leukemia cells treated with: doxorubicin $0.5 \mu \mathrm{g} / \mathrm{mL}$ (C), methanol extract: 0.0025 $\mu \mathrm{g} / \mathrm{mL}$ (D), $0.025 \mu \mathrm{g} / \mathrm{mL}(\mathrm{E}), 0.25 \mu \mathrm{g} / \mathrm{mL}$ (F), $2.5 \mu \mathrm{g} / \mathrm{mL}(\mathrm{G}), 25 \mu \mathrm{g} / \mathrm{mL}$ (H-I) after $72 \mathrm{~h}$ of incubation. Normal cells without treatments (A-B). Red arrows manifest the cell shrinkage, blue arrows manifest the cell blebbing, yellow arrows manifest the cell fragmentation) 
The methanol extract of $Z$. acanthopodium fruit had an $\mathrm{IC}_{50}$ value of $19.14 \mu \mathrm{g} / \mathrm{mL}$. It means that methanol extract at the concentration of $19.14 \mu \mathrm{g} / \mathrm{mL}$ can inhibit $50 \%$ ( $\left.\mathrm{IC}_{50}\right)$ of the proliferation of murine P388 leukemia cells, while doxorubicin had an $\mathrm{IC}_{50}$ value of $0.02 \mu \mathrm{g} / \mathrm{mL}$ (Figure 2). American National Cancer Institute (NCI) considered $\mathrm{IC}_{50}$ $<30 \mu \mathrm{g} / \mathrm{ml}$ as a potential cytotoxic agent in the preliminary assay (Suffness and Pezzuto 1991), therefore andaliman crude extract was suggested as a potential source of anticancer agent to treat leukemia. Morphological characters of murine P388 leukemia cells were a high density, round shape with green translucent color (Figure 3.a-b). Murine P388 leukemia cells induced by $0.5 \mu \mathrm{g} / \mathrm{mL}$ doxorubicin as a positive control caused cell shrinkage (red arrows) then lead to cell death. It indicated that doxorubicin killed leukemia cells through apoptotic mechanisms because cells were broken down and then bleb (blue arrows) and formed cell fragmentations (yellow arrows) (Elmore 2007; Furusawa et al. 2001). A similar mechanism was indicated by cells treated with methanol extract of $Z$. acanthopodium fruit. The red arrow in Figure 3.i. shows that methanol extract induced cell shrinkage and bleb in the murine P388 leukemia cells, but the cell fragmentation was not found in the treatment of methanol extract. Cell shrinkage and cell fragmentation are detected as the early stage of apoptosis, which leads to the formation of apoptotic cells as the late stage in the apoptosis mechanisms (Fink and Cookson 2005; Elmore 2007).

Further study is strongly suggested to determine the mechanism of inhibition of $Z$. acanthopodium fruit extract against cancer cells. This study showed that $Z$. acanthopodium fruit extract has the potential as a natural anticancer against murine P388 leukemia cells. Bioactivity of $Z$. acanthopodium fruit extract may be due to the presence of several bioactive compounds. Several terpenes and terpenoids derivatives have been reported as an anticancer agent such as geranyl acetate, caryophyllene, and $\beta$-myrcene (da Silva et al. 2007; Li et al. 2013). Results of GC-MS analysis showed that the methanol extract of $Z$. acanthopodium fruit contained geranyl acetate $(26.72 \%)$ as the main compound (Table 3$)$.

In conclusion, methanol extract of $Z$. acanthopodium fruit from Parsoburan village, Toba Samosir, North Sumatra, did not present any antibacterial activity against all aquaculture pathogens tested (Tenacibaculum maritimum, Vibrio alginolyticus, $V$. anguillarum, $V$. harveyi). However, methanol extract showed cytotoxic activity against murine P388 leukemia cells with an $\mathrm{IC}_{50}$ value of $19.14 \mu \mathrm{g} / \mathrm{mL}$. Phytochemical content of $Z$. acanthopodium fruit was alkaloid, flavonoid, saponin, steroid, triterpenoid, and tannin derivatives. The GC/MS analysis discovered the presence of 20 identified secondary metabolites in methanol extract, and geranyl acetate as its major metabolite.

\section{ACKNOWLEDGEMENTS}

The authors gratefully acknowledge the full financial support of Toyama Prefectural University, Japan. This manuscript is an outcome of a fellowship activity of Dr. Mada Triandala Sibero in Toyama Prefectural University, Japan (2019-2020)

\section{REFERENCES}

AOAC. 2019. Official Methods of Analysis, 21st ed. The Association of Official Analytical Chemists, Rockville, MD.

Appelhans MS, Reichelt N, Groppo M, Paetzold C, Wen J. 2018. Phylogeny and biogeography of the pantropical genus Zanthoxylum and its closest relatives in the proto-Rutaceae group (Rutaceae). Mol Phylogenet Evol 126: 31-44. DOI: 10.1016/j.ympev.2018.04.013

Asbur Y, Khairunnisyah. 2018. Utilization andaliman (Zanthoxylum acanthopodium DC) for producing plant essential oils. Jurnal Kultivasi 17 (1): 537-543. DOI: 10.24198/kltv.v17i1

Bacon K, Boyer R, Denbow C, O'Keefe S, Neilson A, Williams R. 2017. Evaluation of different solvents to extract antibacterial compounds from jalapeño peppers. Food Sci Nutr 5: 497-503. DOI: $10.1002 \% 2 \mathrm{Ffsn} 3.423$

Bhandary S, Kumari SN, Bhat VS, Sharmila K, Bekal MP. 2012. Preliminary phytochemical screening of various extracts of Punica granatum peel, whole fruit and seeds. Nitte Univ J Health Sci 2 (4): 34-38.

da Silva F, Santos N, Pascon R, Vallim M, Figueiredo C, Martins R, Sartorelli P. 2017. Chemical composition and In Vitro cytotoxic and antimicrobial activities of the essential oil from leaves of Zanthoxylum monogynum St. Hill (Rutaceae). Medicines 4 (2): 31. DOI: $10.3390 /$ medicines4020031

da Silva SL, Figueiredo PM, Yano T. 2007. Cytotoxic evaluation of essential oil from Zanthoxylum rhoifolium Lam. leaves. Acta Amazonica 37 (2): 281-286. DOI: 10.1590/s004459672007000200015

Elmore S. 2007. Apoptosis: A review of programmed cell death. Toxicol Pathol 35 (4): 495-516. DOI: 10.1080/01926230701320337

Fink SL, Cookson BT. 2005. Apoptosis, pyroptosis, and necrosis: Mechanistic description of dead and dying eukaryotic cells. Infect Immun 73 (4): 1907-1916. DOI: 10.1128/IAI.73.4.1907

Furusawa S, Nakano S, Wu J, Sakaguchi S, Takayanagi M, Sasaki KI, Satoh S. 2001. Apoptosis induced by doxorubicin and cinchonine in P388 multidrug-resistant cells. J Pharma Pharmacol 53 (7): 10291039. DOI: $10.1211 / 0022357011776289$

Harborne JB. 1973. Phytochemical Methods. Springer, UK. DOI: 10.1007/978-94-009-5921-7

Hedberg N, Stenson I, Nitz PM, Warshan D, Nguyen-Kim H, Tedengren M, Kautsky N. 2018. Antibiotic use in Vietnamese fish and lobster sea cage farms; implications for coral reefs and human health. Aquaculture 495: 366-375. DOI: 10.1016/j.aquaculture.2018.06.005

Julistiono H, Lestari FG, Iryanto R, Lotulung PD. 2018. Antimycobacterial activity of fruit of Zanthoxylum acanthopodium DC against Mycobacterium smegmatis. Avicenna J Phytomed 8 (5): 432-438.

Junaedi DI, Nurlaeni Y. 2019. Ecology of Zanthoxylum acanthopodium: Specific leaf area and habitat characteristics. Biodiversitas 20 (3): 732-737. DOI: $10.13057 /$ biodiv/d200317

Khattak KF, Rahman TR. 2015. Effect of geographical distributions on the nutrient composition, phytochemical profile and antioxidant activity of Morus nigra. Pakistan J Pharmaceut Sci 28 (5): 16711678.

Khlif I, Jellali K, Michel T, Halabalaki M, Skaltsounis AL, Allouche N. 2015. Characteristics, phytochemical analysis and biological activities of extracts from Tunisian chetoui, Olea europaea variety. J Chem. DOI: $10.1155 / 2015 / 418731$

Kovach CW, Kurdziel JP, Bowman R, Wagner J, Lawrence JM. 1992. The effects of stress and disturbance on proximate composition, allocation of production, photosynthesis, respiration, and chlorophyll levels in Hygrophila polysperma (Roxb.) Anders. (Acanthaceae. Environ Exp Bot 32 (4): 479-486. DOI: 10.1016/0098-8472 (92)90061-6

Kristanty RE, Suriawati J. 2015. The Indonesian Zanthoxylum acanthopodium DC.: Chemical and biological values. Intl J PharmTech Res 8 (6): 313-321.

Kumar V, Reddy SGE, Chauhan U, Kumar N, Singh B. 2016. Chemical composition and larvicidal activity of Zanthoxylum armatum against 
diamondback moth, Plutella xylostella. Natl Prod Res 30 (6): 689692. DOI: $10.1080 / 14786419.2015 .1036270$

Li X, Dierckens K, Bossier P, Defoirdt T. 2018. The impact of quorum sensing on the virulence of Vibrio anguillarum towards genotobiotic sea bass (Dicentrarchus labrax) larvae. Aquacult Res 49 (11): 36863689. DOI: $10.1111 /$ are. 13821

Li Z, Han S, Jiang J, Zhang X, Li Y, Chen H, Yuan Y. 2013. Antitumor compound identification from Zanthoxylum bungeanum essential oil based on composition-activity relationship. Chem Res Chinese Univ 29 (6): 1068-1071. DOI: 10.1007/s40242-013-3223-3

Liu L, Ge M, Zheng X, Tao Z, Zhou S, Wang G. 2016. Investigation of Vibrio alginolyticus, $V$. harveyi, and $V$. parahaemolyticus in large yellow croaker, Pseudosciaena crocea (Richardson) reared in Xiangshan Bay, China. Aquacult Rep 3: 220-224. DOI: 10.1016/j.aqrep.2016.04.004

Liu X, Steele JC, Meng XZ. 2017. Usage, residue, and human health risk of antibiotics in Chinese aquaculture: A review. Environ Pollut 223: 161-169. DOI: 10.1016/j.envpol.2017.01.003

María R, Shirley M, Xavier C, Jaime S, David V, Rosa S, Jodie D. 2018. Preliminary phytochemical screening, total phenolic content and antibacterial activity of thirteen native species from Guayas province Ecuador. J King Saud Univ 30 (4): 500-505. DOI: 10.1016/j.jksus.2017.03.009

Mbah BO, Eme PE, Paul AE. 2012. Effect of drying techniques on the proximate and other nutrient composition of Moringa oleifera leaves from two areas in Eastern Nigeria. Pak J Nutr 11 (11): 1044-1048.

Mo WY, Chen, Z, Leung, HM, Leung, AOW. (2015). Application of veterinary antibiotics in China's aquaculture industry and their potential human health risks. Environ Sci Poll Res 24 (10): 89788989. DOI: $10.1007 / \mathrm{s} 11356-015-5607-\mathrm{z}$

Muzafri A, Julianti E, Rusmarilin H. 2018. The extraction of antimicrobials component of andaliman (Zanthoxylum acanthopodium DC.) and its application on catfish (Pangasius sutchi) fillet. IOP Conf Ser Earth Environ Sci 122: 012089. DOI: $10.1088 / 1755-1315 / 122 / 1 / 012089$

Oduntant AO, Olaleye O. 2012. Effect of plant maturity on the proximate composition of Sesamum radiatum Schum leaves. J Food Stud 1 (1) 69-76.

Pringgenies D, Yudiati E, Nuraini RAT, Susilo ES, Rahayuningsih E. 2018. Optimal concentration of mangrove (Rhizophora mucronata) leaf and propagule based natural dye. Malaysian J Fund Appl Sci 14 (1-2): 168-173. DOI: $10.11113 /$ mjfas.v14n1-2.1011

Purba EC, Silalahi M, Nisyawati. 2018. Gastronomic ethnobiology of "terites" - a traditional Batak Karo medicinal food: A ruminant's stomach content as a human food resource. J Ethnic Foods 5 (2): 114120. DOI: $10.1016 /$ j.jef.2018.06.002

Rosidah R, Hasibuan PAZ, Haro G, Satria D. 2019. Cytotoxicity activity of ethanol extract of Andaliman fruits (Zanthoxylum acanthopodium DC .) towards 4T1 Breast Cancer Cells. Indon J Pharmaceut Clin Res 2 (2): $31-35$.

Santos L, Ramos F. 2018. Antimicrobial resistance in aquaculture: Current knowledge and alternatives to tackle the problem. Int $\mathrm{J}$ Antimicrob Agents 52 (2): 135-143. DOI: 10.1016/j.ijantimicag.2018.03.010

Saragih DE, Arsita EV. 2019. The phytochemical content of Zanthoxylum acanthopodium and its potential as a medicinal plant in the regions of Toba Samosir and North Tapanuli, North Sumatra. Pros Sem Nas Masy Biodiv Indon 5 (1): 71-76. DOI: 10.13057/psnmbi/m050114.
Satria D, Silalahi J, Haro G, Ilyas S, Hasibuan PAZ. 2019. Chemical analysis and cytotoxic activity of $\mathrm{N}$-hexane fraction of Zanthoxylum acanthopodium DC. fruits. Rasayan J Chem 12 (2): 803-808. DOI: 10.31788/RJC.2019.1225180

Seow LJ, Beh HK, Sadikun A, Asmawi MZ. 2013. Preliminary phytochemical and physicochemical characterization of Gynura segetum (Lour) Merr (Compositae) leaf. Trop J Pharmaceut Res 12 (5): 777-782. DOI: $10.4314 /$ tjpr.v12i5.18

Sharma AR, Zhou T, Harunari E, Oku N, Trianto A, Igarashi Y. 2019. Labrenzbactin from a coral-associated bacterium Labrenzia sp. J Antibiotics 72 (8): 634-639. DOI: 10.1038/s41429-019-0192-x

Sibero MT, Radjasa OK, Bondar KG, Simbolon LMI, Meilana L, Ayuningrum D. 2019. Antibacterial activity and phytochemical content of Holothuria atra from Panjang Island, Jepara, Indonesia. AIP Conf Proc 2120: 080005. DOI: 10.1063/1.5115743.

Sinaga AOY, Putri LAP, Siregar LAM. 2015. Genetic diversity analysis of andaliman (Zanthoxylum acanthopodium DC.) germplasm in North Sumatra using RAPD Marker. Jurnal Online Agroteknologi 3 (2): 5467. DOI: http://repositorio.unan.edu.ni/2986/1/5624.pdf

Singh TP, Singh OM. 2011. Phytochemical and pharmacological profile of Zanthoxylum armatum DC. - An overview. Indian J Natl Prod Resour 2 (3): 275-285.

Siregar BL. 2003. Andaliman (Zanthoxylum acanthopodium DC.) in North Sumatra: Description and germination. Hayati 10 (1), 38-41.

Småge SB, Frisch K, Brevik ØJ, Watanabe K, Nylund A. 2016. First isolation, identification and characterisation of Tenacibaculum maritimum in Norway, isolated from diseased farmed sea lice cleaner fish Cyclopterus lumpus L. Aquaculture 464: 178-184. DOI: 10.1016/j.aquaculture.2016.06.030.

Suffness, M. and Pezzuto, J.M. (1991) Assays related to cancer drug discovery. In: Hostettmann K (ed.). Methods in Plant Biochemistry, Vol. 6, Assays for Bioactivity, Academic Press, London.

Syari DM, Rosidah R, Hasibuan PAZ, Haro G, Satria D. 2019. Evaluation of cytotoxic activity alkaloid fractions of Zanthoxylum acanthopodium DC. fruits. Open Access Macedonian J Med Sci 7 (22): 3745-3747. DOI: 10.3889/oamjms.2019.495.

Tantapakul C, Phakhodee W, Ritthiwigrom T, Yossathera K, Deachathai S, Laphookhieo S. 2012. Antibacterial compounds from Zanthoxylum rhetsa. Arch Pharma Res 35 (7): 1139-1142. DOI: 10.1007/s12272012-0703-9.

Tantapakul C, Phakhodee W, Ritthiwigrom T, Yossathera K, Deachathai S, Laphookhieo S. 2012. Antibacterial compounds from Zanthoxylum rhetsa. Arch Pharma Res 35 (7): 1139-1142. DOI: 10.1007/s12272012-0703-9.

Vihotogbe AS, Anihouvi BV, Akissoe HN, Amadji LG, Hounhouigan DJ. 2013. Effect of organic and mineral fertilization on proximate composition of three leafy vegetables harvested at different periods. Intl J Biol Chem Sci 7 (1): 271-286.

WHO. 2019. Indonesia Source GLOBOCAN 2018. International Agency for Research on Cancer 256: 1-2.

Wijaya CH, Hadiprodjo IT, Apriyantono A. 2002. Identification of volatile compounds and key aroma compounds of Andaliman fruit (Zanthoxylum acanthopodium). Food Sci Biotechnol 11 (6): 680-683.

Wijaya CH, Napitupulu FI, Karnady V, Indariani S. 2019. A review of the bioactivity and flavor properties of the exotic spice "Andaliman" (Zanthoxylum acanthopodium DC.). Food Rev Intl 35 (1): 1-19. DOI: 10.1080/87559129.2018.1438470 